\title{
Microcosm Biofilm Formation on Titanium Surfaces
}

\author{
Claudio Zeferino Dal'Agnol", Letícia Stefenon ${ }^{a}$,Françoise Hélène van De Sande
} Álvaro Della Bona ${ }^{a}$, Maximiliano Sérgio Cenci ${ }^{b}$,Bruna Webber', Laura Beatriz Rodrigues ${ }^{c}$, Luciana Ruschel dos Santos ${ }^{c *}$

\author{
${ }^{a}$ Programa de Pós-Graduação em Odontologia, Universidade de Passo Fundo - UPF, \\ BR 285, s/n, Bairro São José, Passo Fundo, RS, Brazil \\ ' Programa de Pós-Graduação em Odontologia, Universidade Federal de Pelotas - UFPEL, \\ Rua Gonçalves Chaves, 457, Pelotas, RS, Brazil \\ 'Programa de Pós-Graduação em Bioexperimentação, Universidade de Passo Fundo - UPF, \\ BR 285, s/n, Bairro São José, Passo Fundo, RS, Brazil
}

Received: May 30, 2014; Revised: July 3, 2015

\begin{abstract}
Risk factors associated with peri-implantitis are related to the biofilm composition around the implant and the ability of bacterial adhesion. This study evaluated the biofilm formation on different surfaces of commercially pure titanium (CP Ti) grade 4 after 12, 24, 48 and 168 hours using the microcosm technique and scanning electron microscopy (SEM). The following surface conditions were examined: S (control)- smooth and plain; B- sand-blasted with aluminum oxide; E- etched using nitric acid; and BE- the combination of J and A treatments. Statistical differences on biofilm formation $(\mathrm{CFU} / \mathrm{mg}$ ) were found between the control (S) and B surfaces at the first 12 hours, which are related to the lowest $\left(\mathrm{R}_{\mathrm{a}}=0.21 \mu \mathrm{m}\right)$ and highest $\left(\mathrm{R}_{\mathrm{a}}=0.62 \mu \mathrm{m}\right)$ mean roughness values. At 168-hour all surfaces showed similar biofilm formation. Yet, microbial growth occurred on all surfaces, regardless of the surface treatment.
\end{abstract}

Keywords: titanium, microcosm, biofilms, peri-implantitis

\section{Introduction}

In Dentistry, titanium implants are used as the material of choice for a wide variety of cases, from the replacement of a single dental element to complete restorations ${ }^{1-5}$. Titanium is indicated because of its excellent mechanical, physicochemical and biochemical properties, tissue tolerance, biocompatibility ${ }^{6-8}$, hardness, corrosion resistance and bonelike modulus of elasticity ${ }^{2}$.

The technological evolution of implants has enabled the development of models with different surface topographies ${ }^{9}$, increasing the available area and allowing for osseointegration ${ }^{10,11}$. Changes in the topography and in the surface free energy of titanium are possible through surface treatment using, for example, abrasive particles (sand-blasting) and acid etching ${ }^{12}$. Although surface roughness benefits osseointegration, it may facilitate the accumulation of microbial species and lead to peri-implant infection, resulting in bone destruction and failure of restorations with this type of biomaterial ${ }^{13,14}$.

Human dental plaque is a complex biofilm with different concentrations of bacterial species in different environments and in vivo study is hindered due to its heterogeneity, available amount and limited access, in addition to ethical problems. Considering these limitations, Wong \& Sissons ${ }^{15}$ developed an "artificial mouth" plaque culture system in order to investigate microcosm and to minimize the limitations of biofilm studies. Microcosm is defined as a microbiological

*e-mail: luruschel@upf.br entity that represents the natural in vitro dental plaque. This way, microcosm maintains the natural complexity of the oral biofilm, its biodiversity and its heterogeneous structure ${ }^{16}$. The aim of this study was to evaluate the biofilm formation in different time periods on titanium surfaces submitted to different surface treatments using the microcosm technique.

\section{Material and Methods}

The study protocol (no. 141/2012) was approved by the local Ethics in Research Committee. A randomized in vitro study was performed, in which biofilms were allowed to form in microplates on titanium discs and saliva (microcosm) was used as inoculum. The saliva was collected from a nonsmoking donor with periodontal disease that did not take antibiotics for 30 days and abstained from oral hygiene for 24 hours before saliva collection. The selection parameters were periodontal pockets deeper than $4 \mathrm{~mm}$ with bleeding and/or suppuration at periodontal probing and with clinical insertion levels of approximately $7 \mathrm{~mm}$. Titanium specimens (164) were fabricated, 40 specimens were assigned for each surface treatment and biofilm experiment, and four were randomly selected for SEM analysis without biofilm formation. Biofilms were grown up to $12,24,48$ and 168 hours $(n=10)$. At each time-point, 9 specimens were used for microbiological analysis and 1 specimen was randomly selected for SEM analysis. 


\subsection{Specimens}

Titanium specimens were donated by Titanium Fix ${ }^{\circledR}$ - AS Technology Ltda (São José dos Campos, SP, Brazil) measuring $5 \mathrm{~mm}$ in diameter and $3 \mathrm{~mm}$ in thickness with surface treatments as follows:

$\mathbf{S}$ (control)- smooth, plain surface;

B- sand-blasted with aluminum oxide;

E- etched with nitric acid; and

BE- sand-blasted with aluminum oxide and etched with nitric acid.

The initial roughness of a disc in each condition was measured by an optical profilometer (Surr-Corder SE1200 - Koxaka Lab, Tokyo, Japan), calibrated with V 200, $\mathrm{H} 25 \mathrm{~mm} / \lambda \mathrm{c}$ and $\lambda \mathrm{c} 0.25 \mathrm{~mm}$, and the mean roughness $\left(\mathrm{R}_{\mathrm{a}}\right)$ was used for comparison of the surfaces. For each specimen, three measurements were performed on each side and in different directions to obtain the mean roughness (ABNT NBR ISO 4288).

\subsection{Artificial saliva (DMM) preparation}

The artificial saliva or defined medium mucin (DMM) was obtained as proposed by Wong \& Sissons ${ }^{15}$ : porcine gastric mucin $(2.5 \mathrm{~g} / \mathrm{L})$, urea $(1.0 \mathrm{mmol} / \mathrm{L})$, salts (in mmol/L $\left(\mathrm{CaCl}_{2}, 1.0 ; \mathrm{MgCl}_{2}, 0.2 ; \mathrm{KH}_{2} \mathrm{PO}_{4}, 3.5 ; \mathrm{K}_{2} \mathrm{HPO}_{4}, 1.5\right.$; $\left.\mathrm{NaCl}, 10.0 ; \mathrm{KCl}, 15.0 ; \mathrm{NH}_{4} \mathrm{Cl}, 2.0\right), 21$ free amino acids, 17 vitamins, and growth factors. The medium contained amino acids for the protein/peptide equivalent (in $\mathrm{mmol} / \mathrm{L}$ ), whose concentrations are based on human saliva. The amino acids included alanine (1.95), arginine (1.30), asparagine (1.73), aspartic acid (1.52), cysteine (0.05), glutamic acid (5.41), glutamine (3.03), glycine (1.95), histidine (1.08), isoleucine (2.38), leucine (3.68), serine (3.46), threonine (1.08), tryptophan $(0.43)$, tyrosine $(2.17)$, valine $(2.38)$, and casein (5.0).

\subsection{Saliva collection and processing}

Saliva was collected from a donor with periodontal disease. It was stimulated with parafilm (Parafilm "M" ${ }^{\circledR}$, American National Can TM, Chicago, IL, USA) and collected $70 \mathrm{~mL}$ of saliva that was placed in a sterile graded collector and transported in a foam ice chest to the local Laboratory of Microbiology. The saliva was filtered in sterile glass wool and homogenized in a vortex mixer ${ }^{17,18}$. An aliquot of such saliva was used for bacterial quantification $(\mathrm{CFU} / \mathrm{mL})$.

\subsection{Biofilm growth}

The titanium specimens was inoculated on microplates with $400 \mu \mathrm{L}$ of the prepared saliva. After 60 minutes, the saliva was gently aspirated and $1.8 \mathrm{~mL}$ of artificial saliva was added to each microplate. The plates were incubated under anaerobic conditions $\left(80 \% \mathrm{~N}_{2}, 10 \% \mathrm{CO}_{2}\right.$ and $\left.10 \% \mathrm{H}_{2}\right)$ at $37^{\circ} \mathrm{C}$ for up to 168 hours and the plates were stirred on a daily basis and the supernatant was removed, the $\mathrm{pH}$ was measured (pH meter - Analion PM608 Plus, São Paulo, SP) and the DMM was replaced. After 12, 24, 48 and 168 hours of incubation ${ }^{19,20}$, the discs were removed from the wells with sterile tweezers and the non-adherent cells were gently removed by washing with sterile saline $(2 \mathrm{~mL})$. After that, the discs were placed in tubes containing $1 \mathrm{~mL}$ of reduced transport fluid (RTF) and sonicated (Sonicador Vibra Cell
- Sonics and Materials, Danbury, CT, USA) at $40 \mathrm{~W}$ and at a range of $5 \%$, using six pulses of $9.9 \mathrm{~s}$ each. Thereafter, the suspensions were serially diluted to $10^{7}$, inoculated in duplicate on blood agar and incubated under anaerobic conditions $\left(80 \% \mathrm{~N}_{2}, 10 \% \mathrm{CO}_{2}, 10 \% \mathrm{H}_{2}\right)$ at $37{ }^{\circ} \mathrm{C}$ for $96 \mathrm{~h}$. The colony forming units were counted and the results were expressed in CFU/mg of biofilm specimen (dry weight) ${ }^{21}$.

\subsection{Preparation of samples for scanning electron microscopy (SEM)}

The specimens were placed in 24-well microplates and immersed in $2.5 \%$ glutaraldehyde solution in phosphate buffer to transport to the local Center for Electron Microscopy to exam under SEM (JSM 6060), with a voltage from 0.1 to $30 \mathrm{Kv}$.

\subsection{Statistical analysis}

The results were statistically analyzed using two-way ANOVA and Tukey tests $(\alpha=0.05)$, based on the normal distribution model and equal variance (IBM SPSS Statistics Software version 2.0).

\section{Results and Discussion}

The roughness and biofilm formation values are summarized in Tables 1 and 2. Representative SEM images of the biofilm formation on different titanium treated surfaces are shown in Figure 1. At first 12 hours the biofilm formation was greater on the sand-blasted (B) surface than on S or E surfaces. At 24 hours the B surface showed greater biofilm formation than E surface, which was not different from $\mathrm{S}$ and BE surfaces. At 48 hours, biofilm formation was greater on BE surface than on S surface. At 168 hours, there was no statistical difference in biofilm formation between all examined surfaces $(p>0.05)$.

It has been reported that bacterial biofilm formation on dental restorative materials is a clinical problem, and on dental implants it has been associated to peri-implantitis $2,8,13,14,22,23$. The microcosm technique or "artificial mouth" developed by Wong and Sissons ${ }^{15}$ has already been explored for the assessment of antimicrobial substances and in the field of cariology ${ }^{16-18,24-28}$. However, few studies exist on adhesion and biofilm formation on titanium surfaces and on peri-implantitis ${ }^{29}$.

In the present study, microcosm was used to simulate the oral environment as to the multi-strain behavior of the bacteria found in human saliva, especially in periodontal patients. Another advantage of using microcosm is the feasibility of biofilm study on a large scale through the use of

Table 1. Values for the three roughness measurements and the average roughness value (in $\mu \mathrm{m}$ ) of titanium discs with different surface treatments.

\begin{tabular}{ccccc}
\hline $\begin{array}{c}\text { Surface } \\
\text { treatments }\end{array}$ & $\begin{array}{c}\text { Roughness measurements } \\
\mathbf{1}^{\text {st }} \mathbf{2}^{\text {nd }} \mathbf{3}^{\text {rd }}\end{array}$ & $\begin{array}{c}\text { Mean } \\
\text { roughness } \\
\left(\mathbf{R}_{\mathbf{a}}\right)\end{array}$ \\
\hline Smooth & 0.196 & 0.256 & 0.191 & 0.214 \\
Sand-blasted & 0.632 & 0.583 & 0.658 & 0.624 \\
Acid-etched & 0.316 & 0.313 & 0.335 & 0.321 \\
$\begin{array}{c}\text { Sand-blasted } \\
\text { and acid-etched }\end{array}$ & 0.538 & 0.493 & 0.499 & 0.510 \\
\hline
\end{tabular}


artificial saliva (DMM) and appropriate nutritional conditions for biofilm growth. By using titanium discs with different topographies, biofilm growth periods, and multiplication conditions in an "artificial mouth", it is possible to observe the adhesion, concentration and biomass of microorganisms in different time periods and on different surfaces.

Saliva was collected from periodontal patients because it was reported that the microbiota in peri-implantitis is similar to the one found in periodontal disease, as well as its pathogenesis ${ }^{30}$. This correlation between biofilm accumulation and presence of periodontal pathogens at the level of bone loss and around the peri-implant tissue has been well reported ${ }^{30-37}$. However, peri-implantitis does not occur without previous adhesion and subsequent microbial colonization. Adhesion depends on the type of microorganism, on the physicochemical properties of the implant surface and on the presence of oral fluids between the microorganisms and the surfaces ${ }^{38-42}$, as well as on the control procedures associated with oral hygiene $\mathrm{A}^{43,44}$

Initial biofilm formation may be influenced by the implant surface and the adhesion of microorganisms seems to be directly proportional to surface roughness ${ }^{35,43,45-51}$. Other studies also confirm the relationship between surface roughness and the efficiency for osseointegration ${ }^{52-55}$. Thus, the rougher the surface, the larger the accumulation of biofilm ${ }^{46,48}$, and the greater the chances for clinical failure due to the interplay between these factors.

This issue was investigated by Teughels et al. ${ }^{56}$ and Mioralli ${ }^{57}$, who reported on rough surfaces with larger accumulation and plaque retention and development of more mature plaques, characterized by the increase in the number of colonies, mobile organisms and spirochetes.

Table 2. Incubation period and biofilm formation $\left(\log _{10} \mathrm{CFU} / \mathrm{mg}\right)$ on titanium discs with different surface treatments.

\begin{tabular}{clllll}
\hline Hours & Smooth & Sand-blasted & Acid-etched & $\begin{array}{c}\text { Sand-blasted and } \\
\text { acid-etched }\end{array}$ & p \\
\hline 12 & $7.348 \pm 7.155 \mathrm{AB}$ & $7.622 \pm 7.156 \mathrm{C}$ & $7.241 \pm 6.971 \mathrm{~A}$ & $7.477 \pm 7.084 \mathrm{BC}$ & 0.001 \\
24 & $8.153 \pm 7.561 \mathrm{AB}$ & $8.309 \pm 7.802 \mathrm{~B}$ & $8.103 \pm 7.724 \mathrm{~A}$ & $8.255 \pm 7.628 \mathrm{AB}$ & 0.016 \\
48 & $8.468 \pm 8.1375 \mathrm{~A}$ & $8.619 \pm 8.149 \mathrm{AB}$ & $8.623 \pm 8.163 \mathrm{AB}$ & $8.728 \pm 8.038 \mathrm{~B}$ & 0.013 \\
168 & $8.941 \pm 8.384 \mathrm{NS}$ & $9.014 \pm 8.354 \mathrm{NS}$ & $8.878 \pm 8.520 \mathrm{NS}$ & $8.984 \pm 8.571 \mathrm{NS}$ & 0.358 \\
\hline
\end{tabular}

NS: not significant. Means followed by same letters in the line are not statistically different (Student-Newman-Keuls test, $\mathrm{p} \leq 0.05$ ).
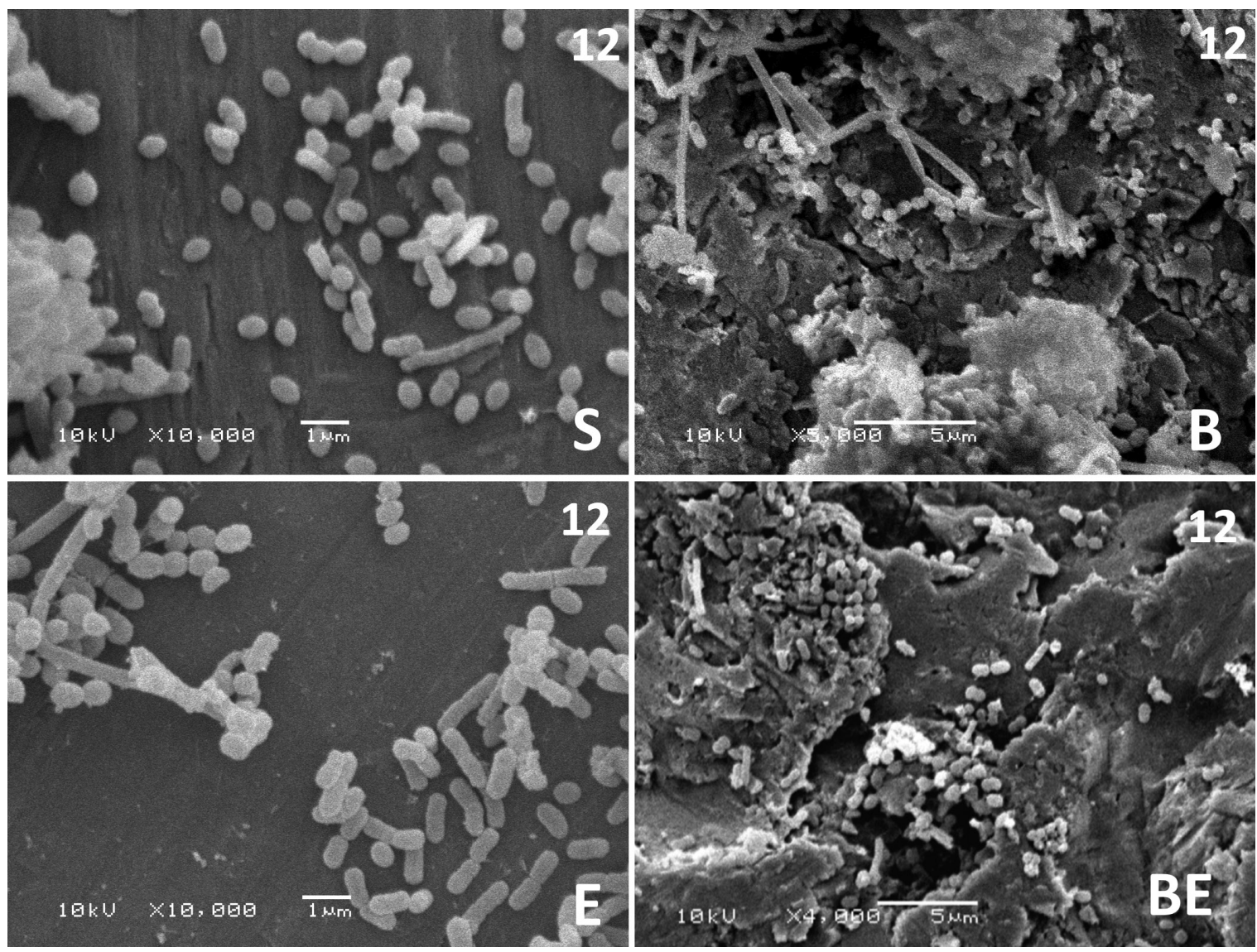

Figure 1. Photomicrograph of smooth titanium surface (control - S), sand-blasted with aluminum oxide (B), etched with nitric acid (E) and sand-blasted with aluminum oxide and etched with nitric acid (BE) after 12 hours of biofilm formation. 
Ameen et al. ${ }^{58}$ tested the energy components on the surface of several materials to verify the strength of cell adhesion and demonstrated that the surface free energy is more important than roughness for induction of adhesion and cell proliferation.

In the present study, the average surface roughness is summarized in Table 1. Considering the association of roughness and microbial growth (Tables 1 and 2), growth remained constant throughout the study period $(12,24,48$ and 168 hours). Nonetheless, at 12 hours, smooth surfaces (S) and acid-etched surfaces (E) showed the lowest CFUs (7.348 and 7.241, respectively), a fact that can be attributed to the initial adhesion and biofilm formation limited to less rough surfaces, as mentioned by Amoroso et al. ${ }^{2}$ that evaluated in vitro the bacterial adhesion of Porphyromonas gengivalis on titanium discs and the relationship between roughness and free surface energy. They observed that a surface with $\mathrm{R}_{\mathrm{a}}=0.15 \mu \mathrm{m}$, classified as very smooth, showed significant less bacterial adhesion than rougher surfaces $\left(\mathrm{R}_{\mathrm{a}}=0.22 \mu \mathrm{m}\right.$ and $\left.0.45 \mu \mathrm{m}\right)$, which are similar to implants surfaces (around $\mathrm{R}_{\mathrm{a}}=0.35 \mu \mathrm{m}$ ).

In the present study, biofilm formation was smaller at 12 and 24 hours on less rough surfaces ( $S$ and $E$ surfaces), in line with the findings of Bürgers et al. ${ }^{21}$, who used sand-blasted titanium discs etched with nitric acid to assess the in vitro bacterial adhesion of Streptococcus sanguinis, confirming that the initial bacterial adhesion on titanium surfaces is primarily influenced by surface roughness.

At the end of the present experiment (168 hours), there was no statistical significance $(p>0.05)$ between CFUs on the evaluated surfaces. Although the control surface $(\mathrm{R}=0.21 \mu \mathrm{m})$ presented one third of the roughness value of $\mathrm{B}$ surface $\left(R_{a}=0.624 \mu \mathrm{m}\right)$ the biofilm formation was statistically

\section{References}

1. Mabboux F, Ponsonnet L, Morrier JJ, Jaffrezic N and Barsotti O. Surface free energy and bacterial retention to saliva-coated dental implant materials--an in vitro study. Colloids and Surfaces. B, Biointerfaces. 2004; 39(4):199-205. http://dx.doi. org/10.1016/j.colsurfb.2004.08.002. PMid:15555904.

2. Amoroso PF, Adams RJ, Waters MGJ and Williams DW. Titanium surface modification and its effect on the adherence of Porphyromonas gingivalis: an in vitro study. Clinical Oral Implants Research. 2006; 17(6):633-637. http://dx.doi. org/10.1111/j.1600-0501.2006.01274.x. PMid:17092220.

3. Elter C, Heuer W, Demling A, Hannig M, Heidenblut T, Bach FW, et al. Supra- and subgingival biofilm formation on implant abutments with different surface characteristics. The International Journal of Oral \& Maxillofacial Implants. 2008; 23(2):327-334. PMid:18548931.

4. Shibli JA, Melo L, Ferrari DS, Figueiredo LC, Faveri M and Feres M. Composition of supra- and subgingival biofilm of subjects with healthy and diseased implants. Clinical Oral Implants Research. 2008; 19(10):975-982. http://dx.doi. org/10.1111/j.1600-0501.2008.01566.x. PMid:18828812.

5. Pye AD, Lockhart DEA, Dawson MP, Murray CA and Smith AJ. A review of dental implants and infection. The Journal of Hospital Infection. 2009; 72(2):104-110. http://dx.doi. org/10.1016/j.jhin.2009.02.010. PMid:19329223. identical for all surface treatments. The relationship between surface treatment with nitric acid etching (E) and the lower amount of microorganisms in the first two assessment periods (12 and 24 hours) may be associated with a decrease in roughness, compared to groups where sand-blasted was used, due to the acid etching process, or to a possible antimicrobial property of the nitric acid. Some studies aimed to maximize the quantity and quality of the bone-implant interface, reported that several changes in the implant surface have been proposed, most of them based on the assumption that a better and quicker osseointegration may be achieved by changing the topography or roughness of the implant ${ }^{52,53,59}$.

Since the $\mathrm{R}_{\mathrm{a}}$ values found in the present study were different between the groups, biological results may not have been influenced by roughness according to the experimental periods assessed (48 to 168 hours) but rather by factors such as irregular surface topography, surface contamination by aluminum (Al) particles or possible changes in the surface energy of the metal by the surface treatments used.

\section{Conclusions}

The microcosm technique showed that microbial growth occured regardless of the surface treatment used, and that biofilm formation was smaller within the first 12 hours on less rough surfaces, suggesting that initial adhesion is directly proportional to surface roughness.

\section{Acknowledgements}

We thank Titanium Fix for providing the titanium specimens used in this study and FAPERGS PqG 12/2523-5 to partial financial support.

6. Bunetel L, Guérin J, Agnani G, Piel S, Pinsard H, Corbel JC, et al. In vitro study of the effect of titanium on porphyromonas gingivalis in the presence of metronidazole and spiramycin. Biomaterials. 2001; 22(22):3067-3072. http://dx.doi.org/10.1016/ S0142-9612(01)00054-0. PMid:11575482.

7. Elias CN, Lima JHC and Santos MV. Modificações nas superfícies dos implantes dentários: da pesquisa básica à aplicação clínica. Revista Implant News. 2008; 5:467-476.

8. Subramani K, Jung RE, Molenberg A and Hämmerle CHF. Biofilm on dental implants: a review of the literature. The International Journal of Oral \& Maxillofacial Implants. 2009; 24(4):616-626. PMid:19885401.

9. Carvalho BM, Pellizer EP, Moraes SLD, Falcón-Antenucci RM and Ferreira Júnior JS. Tratamentos de superfície nos implantes dentários. Revista de Cirurgia e Traumatologia Buco-MaxiloFacial. 2009; 9:123.

10. Brånemark PI, Hansson BO, Adell R, Breine U, Lindström J, Hallén $\mathrm{O}$, et al. Osseointegrated implants in the treatment of the edentulous jaw. Experience from a 10-year period. Scandinavian Journal of Plastic and Reconstructive Surgery. Supplementum. 1977; 16:1-132. PMid:356184.

11. Bränemark PI. Tissue-integrated prostheses. Chicago: Quintessence Publishing Company; 1986. p. 99-116.

12. Rosenberg ES. A comparison of characteristics of implant failure and survival in periodontally healthy patients: a clinical report. 
The International Journal of Oral \& Maxillofacial Implants. 2004; 19(6):873-879. PMid:15623064.

13. Grössner-Schreiber B, Teichmann J, Hannig M, Dörfer C, Wenderoth DF and Ott SJ. Modified implant surfaces show different biofilm compositions under in vivo conditions. Clinical Oral Implants Research. 2009; 20(8):817-826. http://dx.doi. org/10.1111/j.1600-0501.2009.01729.x. PMid:19508342.

14. Gonçalves F, Zanetti LZ, Zanetti RV and Ramalho AS. Estudo in vitro do laser de diodo $980 \mathrm{~nm}$ na desinfecção de implantes. Revista Gaucha de Odontologia. 2009; 57:395-399.

15. Wong $L$ and Sissons C. A comparison of human dental plaque microcosm biofilms grown in an undefined medium and a chemically defined artificial saliva. Archives of Oral Biology. 2001; 46(6):477-486. http://dx.doi.org/10.1016/S00039969(01)00016-4. PMid:11311195.

16. Sissons CH, Cutress TW, Hoffman MP and Wakefield JSJ. A multi-station dental plaque microcosm (artificial mouth) for the study of plaque growth, metabolism, $\mathrm{pH}$, and mineralization. Journal of Dental Research. 1991; 70(11):1409-1416. http:// dx.doi.org/10.1177/00220345910700110301. PMid:1960250.

17. Filoche SK, Coleman MJ, Angker L and Sissons CH. A fluorescence assay to determine the viable biomass of microcosm dental plaque biofilms. Journal of Microbiological Methods. 2007a; 69(3):489-496. http://dx.doi.org/10.1016/j.mimet.2007.02.015. PMid:17408789.

18. Filoche SK, Soma KJ and Sissons CH. Caries-related plaque microcosm biofilms developed in microplates. Oral Microbiology and Immunology. 2007b; 22(2):73-79. http:// dx.doi.org/10.1111/j.1399-302X.2007.00323.x. PMid:17311629.

19. Leonhardt A and Dahlen G. Effect of titanium on selected oral bacterial species in vitro. European Journal of Oral Sciences. 1995; 103(6):382-387. http://dx.doi.org/10.1111/j.1600-0722.1995. tb01861.x. PMid:8747674.

20. Schwarz F, Sculean A, Wieland M, Horn N, Nuesry E, Bube $\mathrm{C}$, et al. Effects of hydrophilicity and microtopography of titanium implant surfaces on initial supragingival plaque biofilm formation. A pilot study. Mund-, Kiefer-und Gesichtschirurgie. 2007; 11(6):333-338. http://dx.doi.org/10.1007/s10006-0070079-z. PMid:17940813.

21. Bürgers R, Gerlach T, Hahnel S, Schwarz F, Handel G and Gosau M. In vivo and in vitro biofilm formation on two different titanium implant surfaces. Clinical Oral Implants Research. 2010; 21(2):156-164. http://dx.doi.org/10.1111/j.16000501.2009.01815.x. PMid:19912269.

22. Busscher HJ, Rinastiti M, Siswomihardjo W and van der Mei HC. Biofilm formation on dental restorative and implant materials. Journal of Dental Research. 2010; 89(7):657-665. http://dx.doi.org/10.1177/0022034510368644. PMid:20448246.

23. Soukos NS and Goodson JM. Photodynamic therapy in the control of oral biofilms. Periodontology 2000. 2011; 55(1):143166. http://dx.doi.org/10.1111/j.1600-0757.2010.00346.x. PMid:21134233.

24. Sissons CH, Cutress TW, Hoffman MP and Wakefield JSJ. Artificial dental plaque biofilm model systems. Advances in Dental Research. 1997; 11(1):110-126. http://dx.doi.org/10.1 177/08959374970110010201. PMid:9524448.

25. Filoche SK, Soma D, van Bekkum M and Sissons CH. Plaques from different individuals yield different microbiota responses to oral-antiseptic treatment. FEMS Immunology and Medical Microbiology. 2008; 54(1):27-36. http://dx.doi.org/10.1111/j.1574695X.2008.00443.x. PMid:18647353.

26. Leite FHVS. Desenvolvimento de um modelo de biofilme para avaliação de potencial anticariogênico de tratamentos e materiais restauradores. [Dissertation]. Pelotas: Universidade Federal de Pelotas; 2009.

27. van de Sande FH, Azevedo MS, Lund RG, Huysmans MCDNJM and Cenci MS. An in vitro biofilm model for enamel demineralization and antimicrobial dose-response studies. Biofouling. 2011; 27(9):1057-1063. http://dx.doi.org/10.108 0/08927014.2011.625473. PMid:22044385.

28. Zaura E, Buijs MJ, Hoogenkamp MA, Ciric L, Papetti A, Signoretto $\mathrm{C}$, et al. The effects of fractions from shiitake mushroom on composition and cariogenicity of dental plaque microcosms in an in vitro caries model. Journal of Biomedicine \& Biotechnology. 2011; 2011:135034. http://dx.doi.org/10.1155/2011/135034. PMid:21941428.

29. Stefenon L. Desenvolvimento de biofilme em superficie de titânio e esmalte. [Dissertation]. Passo Fundo: Universidade de Passo Fundo; 2012.

30. Heydenrijk K, Meijer HJA, van der Reijden WA, Raghoebar GM, Vissink A and Stegenga B. Microbiota around root-form endosseous implants: a review of the literature. The International Journal of Oral \& Maxillofacial Implants. 2002; 17(6):829-838. PMid:12507243.

31. Rams TE and Link CC Jr. Microbiology of failing dental implants in humans: electron microscopic observations. The Journal of Oral Implantology. 1983; 11(1):93-100. PMid:6584637.

32. Rams TE, Roberts TW, Tatum H Jr and Keyes PH. The subgingival microbial flora associated with human dental implants. J Prothetic Dent. 1984; 51(4):529-534. http://dx.doi. org/10.1016/0022-3913(84)90309-3. PMid:6374110.

33. Mombelli A, van Oosten MAC, Schürch E Jr and Land NP. The microbiota associated with successful or failing osseointegrated titanium implants. Oral Microbiology and Immunology. 1987; 2(4):145-151. http://dx.doi.org/10.1111/j.1399-302X.1987. tb00298.x. PMid:3507627.

34. Gatewood RR, Cobb CM and Killoy WJ. Microbial colonization on natural tooth structure compared with smooth and plasmasprayed dental implant surfaces. Clinical Oral Implants Research. 1993; 4(2):53-64. http://dx.doi.org/10.1034/j.16000501.1993.040201.x. PMid:8218744.

35. Quirynen M, De Soete M and van Steenberghe D. Infectious risks for oral implants: a review of the literature. Clinical Oral Implants Research. 2002; 13(1):1-19. http://dx.doi. org/10.1034/j.1600-0501.2002.130101.x. PMid:12005139.

36. Fürst MM, Salvi GE, Lang NP and Persson GR. Bacterial colonization immediately after installation on oral titanium implants. Clinical Oral Implants Research. 2007; 18(4):501508. http://dx.doi.org/10.1111/j.1600-0501.2007.01381.x. PMid:17501978.

37. Silva GLM, Ferreira SD, Zenóbio EG, Soares RV, Costa FO. Mucosite peri-implantar e peri-implantite: prevalência e indicadores de risco em indivíduos parcialmente edêntulos. $R$ Periodontia. 2007; 17(3).

38. Cooper LF. A role for surface topography in creating and maintaining bone at titanium endosseous implants. The Journal of Prosthetic Dentistry. 2000; 84(5):522-534. http://dx.doi. org/10.1067/mpr.2000.111966. PMid:11105008.

39. Quirynen M and Bollen CM. The influence of surface roughness and surface-free energy on supra- and subgingival plaque formation in man. A review of the literature. Journal of Clinical Periodontology. 1995; 22(1):1-14. http://dx.doi. org/10.1111/j.1600-051X.1995.tb01765.x. PMid:7706534.

40. Nassar U, Meyer AE, Ogle RE and Baier RE. The effect of restorative and prosthetic materials on dental plaque. Periodontol. 1995; 8(8):114-124. http://dx.doi.org/10.1111/j.1600-0757.1995. tb00049.x. PMid:9567950. 
41. Busscher HJ and van der Mei HC. Physico-chemical interactions in initial microbial adhesion and relevance for biofilm formation. Advances in Dental Research. 1997; 11(1):24-32. http://dx.doi. org/10.1177/08959374970110011301. PMid:9524439.

42. Jorge AOC. Microbiologia bucal. São Paulo: Santos; 2007.

43. Newman HN. Diet, attrition, plaque and dental disease. Brazilian Dental Journal. 1974; 136(12):491-497. http://dx.doi. org/10.1038/sj.bdj.4803220. PMid:4531943.

44. Quirynen M and Listgarten MA. Distribution of bacterial morphotypes around natural teeth and titanium implants ad modum Brånemark. Clinical Oral Implants Research. 1990; 1(1):8-12. http://dx.doi.org/10.1034/j.1600-0501.1990.010102.x. PMid:2099212.

45. Wise MD and Dykema RW. The plaque-retaining capacity of four dental materials. The Journal of Prosthetic Dentistry. 1975; 33(2):178-190. http://dx.doi.org/10.1016/S0022-3913(75)801089. PMid:1054412.

46. Rimondini L, Farè S, Brambilla E, Felloni A, Consonni C, Brossa $\mathrm{F}$, et al. The effect of surface roughness on early in vivo plaque colonization on titanium. Journal of Periodontology. 1997; 68(6):556-562. http://dx.doi.org/10.1902/jop.1997.68.6.556. PMid:9203099.

47. Esposito M, Hirsch JM, Lekholm U and Thomsen P. Biological factors contributing to failures of osseointegrated oral implants. (I). Success criteria and epidemiology. European Journal of Oral Sciences. 1998; 106(1):527-551. http://dx.doi. org/10.1046/j.0909-8836..t01-2-.x. PMid:9527353.

48. Kawai K, Urano M and Ebisu S. Effect of surface roughness of porcelain on adhesion of bacteria and their synthesizing glucans. The Journal of Prosthetic Dentistry. 2000; 83(6):664-667. http:// dx.doi.org/10.1067/mpr.2000.107442. PMid:10842136.

49. Auschill TM, Arweiler NB, Netuschil L, Brecx M, Reich E and Sculean A. Spatial distribution of vital and dead microorganisms in dental biofilms. Archives of Oral Biology. 2001; 46(5):471476. http://dx.doi.org/10.1016/S0003-9969(00)00136-9. PMid:11286812.

50. Auschill TM, Arweiler NB, Brecx M, Reich E, Sculean A and Netuschil L. The effect of dental restorative materials on dental biofilm. European Journal of Oral Sciences. 2002; 110(1):4853. http://dx.doi.org/10.1046/j.0909-8836.2001.101160.x. PMid:11878760.

51. Konishi N, Torii Y, Kurosaki A, Takatsuka T, Itota T and Yoshiyama M. Confocal laser scanning microscopic analysis of early plaque formed on resin composite and human enamel. Journal of Oral Rehabilitation. 2003; 30(8):790-795. http:// dx.doi.org/10.1046/j.1365-2842.2003.01129.x. PMid:12880401.

52. Klokkevold PR, Nishimura RD, Adachi M and Caputo A. Osseointegration enhanced by chemical etching of the titanium surface. A torque removal study in the rabbit. Clinical Oral Implants Research. 1997; 8(6):442-447. http://dx.doi. org/10.1034/j.1600-0501.1997.080601.x. PMid:9555202.

53. Ong JL, Carnes DL, Cardenas HL and Cavin R. Surface roughness of titanium on bone morphogenetic protein-2 treated osteoblast cells in vitro. Implant Dentistry. 1997; 6(1):19-24. http://dx.doi. org/10.1097/00008505-199700610-00004. PMid:9206401.

54. Sykaras N, Iacopino AM, Marker VA, Triplett RG and Woody RD. Implant materials, designs, and surface topographies: their effect on osseointegration. A literature review. The International Journal of Oral \& Maxillofacial Implants. 2000; 15(5):675-690. PMid:11055135.

55. Fröjd V, Linderbäck P, Wennerberg A, Chávez de Paz L, Svensäter G and Davies JR. Effect of nanoporous TiO2 coating and anodized $\mathrm{Ca} 2+$ modification of titanium surfaces on early microbial biofilm formation. BMC Oral Health. 2011; 11(1):8. http://dx.doi.org/10.1186/1472-6831-11-8. PMid:21385428.

56. Teughels W, Van Assche N, Sliepen I and Quirynen M. Effect of material characteristics and/or surface topography on biofilm development. Clinical Oral Implants Research. 2006;17(Suppl 2):68-81. http://dx.doi.org/10.1111/j.1600-0501.2006.01353.x. PMid:16968383.

57. Mioralli M. Aderência bacteriana e formação de biofilme em superfície de titânio comercialmente puro de uso odontológico. [Dissertation]. São Carlos: Universidade de São Paulo; 2009.

58. Ameen AP, Short RD, Johns R and Schwach G. The surface analysis of implant materials. 1. The surface composition of a titanium dental implant material. Clinical Oral Implants Research. 1993; 4(3):144-150. http://dx.doi.org/10.1034/j.16000501.1993.040305.x. PMid:8297962.

59. Keller JC, Draughn RA, Wightman JP, Dougherty WJ and Meletiou SD. Characterization of sterilized CP titanium implant surfaces. The International Journal of Oral \& Maxillofacial Implants. 1990; 5(4):360-367. PMid:2094654. 